\title{
In-vitro Screening of some Chemicals and Biocontrol Agents against Erwinia carotovora subsp. carotovora, the Causal Agent of Soft Rot of Potato (Solanum tuberosum)
}

\author{
M. Rashid*, M. S. M. Chowdhury and N. Sultana \\ Department of Plant Pathology, Sher-e-Bangla Agricultural University, Dhaka, Bangladesh \\ *Corresponding author and Email: mamun_1961@yahoo.com
}

Received: 11 April $2013 \quad$ Accepted: 06 December 2013

\begin{abstract}
Erwinia carotovora subsp. carotovora was isolated from the infected potato tuber and was identified by pathological, morphological and biochemical studies. Five chemicals viz. Cupravit 50 WP (Copper oxychloride), Sulcox 50 WP (Copper oxychloride), Champion 77 WP (Copper hydroxide), Indofil M45 (Mancozeb) and Bavistin 50 WP (Carbendazim) and five biocontrol agents viz. Bacillus subtilis, Pseudomonas fluorescens, Rhizobium leguminosarum, Trichoderma harzianum and Aspergillus flavus were screened out in vitro against the growth of Erwinia carotovora subsp. carotovora by well diffusion method measuring the inhibition zone. Among the chemicals, Sulcox 50 WP (Copper oxychloride) was highly effective against it with $31.00 \mathrm{~mm}$ inhibition zone after 48 hours of incubation at $0.2 \%$ concentration when $100 \mu \mathrm{l} /$ well was used. In case of biocontrol agents, Bacillus subtilis was the best against the bacterium with $16.67 \mathrm{~mm}$ inhibition zone after 48 hours of incubation.
\end{abstract}

Keywords: Potato, soft rot, in-vitro screening, chemicals, biocontrol agents

\section{Introduction}

Potatoes (Solanum tuberosum) are grown worldwide and the crop is usually considered to be the fourth most important staple food source after rice (Oryza sativa), maize (Zea mays) and wheat (Triticum aestivum) (Czajkowski et al., 2011). It is a popular and important vegetable in Bangladesh. Annual potato production in Bangladesh is 6648 thousand metric tons (WFP, 2013). Erwinia carotovora subsp. carotovora, the causal agent of soft rot of potato is a very economically important pathogen in terms of postharvest losses and is a common cause of decay in stored fruits and vegetables (Pérombelon, 2002). Approximately 22\% of potatoes are lost per year due to viral, bacterial, fungal and pest attack in potato tuber and potato plant, incurring an annual loss of over 65 million tones and bacterial soft rot alone accounts for 30$50 \%$ of this huge loss (Czajkowski et al., 2011). Copper-based compounds provided better control of bacterial soft rot (Blom and Brown, 1999). But the indiscriminate use of agrochemicals leads to degradation of the ecosystem, which may induce pathogen resistance to the pesticide, and may cause human and animal health problems (Huang, 1997). Therefore, public concern is focused on alternative methods of pest control, which can play a role in integrated pest management systems to reduce our dependence on chemical pesticides (Sutton, 1996). Bacillus subtilis, Pseudomonas fluorescens, Rhizobium leguminosarum, Trichoderma harzianum and Aspergillus flavus are most commonly used 
antagonistic organisms against plant pathogen. Bacillus subtilis shows biological activity against phytopatogenic bacteria by producing peptide antibiotics (Backman et al., 1997). Soil fluorescent and non-fluorescent Pseudomonas spp. have shown biological control of soft rot disease of potato by producing a variety of secondary antibacterial metabolites including siderophores, antibiotics and surfactants (Compant et al., 2005). Despite of economic importance, sufficient information has not been generated so far in respect of isolation, identification and management of this disease. Therefore, the current study was conducted to identify the causal agent and evaluate the effect of potential antibacterial chemicals and antagonists against it.

\section{Materials and Methods}

The study was conducted at Disease diagnostic laboratory, Department of Plant Pathology, Sher-eBangla Agricultural University, Dhaka during April, 2012 to March, 2013. The study included the isolation and identification of the causal organism of soft rot of potato and in vitro screening of some chemicals and biocontrol agents against it.

\subsection{Isolation and purification of the causal organism}

Erwinia carotovora subsp. carotovora was isolated from the infected potato tuber collected from a local market of Dhaka. Potato tuber was surface sterilized with $5 \%$ sodium hypochlorite solution for 5 minutes, washed thrice with sterilized distilled water. Sections of lesion margins were placed for 30 minutes in sterile water in a test tube. Tenfold dilution was made from this solution, which was repeated four times to make final dilution up to $10^{-4}$. One hundred micro litre of each dilution was spreaded over NA plates at three replications as described by Goszczynska and Serfontein (1998) and was incubated at $30 \pm 1^{\circ} \mathrm{C}$ for $48 \mathrm{hr}$. Colonies of bacteria were purified on NA plate.

\subsection{Identification of the pathogen}

Identification of the pathogen was done by the following tests:

\subsubsection{Gram's staining reaction}

Part of a young colony was smeared on a glass slide and the bacterium was heat fixed on it. The slide was flooded with Crystal violet solution for 1 minute, rinsed under running tap water for a few seconds and air dried. Then it was flooded with Lugol's iodine solution for 1 minute, decolorized with $95 \%$ Ethanol for 30 seconds and again rinsed with running tap water and air dried. It was counterstained with $0.5 \%$ Safranine for 10 seconds, rinsed under running tap water for a few seconds and air dried. Then the glass slide was examined at $40 \mathrm{x}$ and $100 \mathrm{x}$ magnification using oil immersion (Gerhardt, 1981).

\subsubsection{Biochemical characters}

Gram's staining result was confirmed with potassium hydroxide $(3 \% \mathrm{KOH})$ test (Suslow et al., 1982). During this test, a loopful of bacteria was stirred in $3 \% \mathrm{KOH}$ on a glass slide and any change in the viscosity was recorded. For starch hydrolysis test, pure colony of bacterium was spot inoculated on nutrient agar plate containing $0.2 \%$ soluble starch, incubated at $30 \pm 1^{\circ} \mathrm{C}$ for 48 $\mathrm{hr}$ and flooded with Lugol's iodine solution (Cowan, 1974), the absence or presence of clear zones in stained media was recorded. For catalase test, a few drops of freshly prepared $3 \%$ $\mathrm{H}_{2} \mathrm{O}_{2}$ (Hydrogen peroxide) was added with $48 \mathrm{hr}$ old pure culture of bacteria grown on NA plate (Schaad, 1988) and formation of bubbles were recorded. For oxidase test, part of a colony was smeared onto the moistened oxidase disk containing $1 \mathrm{ml} 1 \%$ aquous $\mathrm{w} / \mathrm{v}$ solution of NNN'N- tetramethyl- p- phenylene- diaminedihydrochloride solution. Colour changed to dark purple was recorded (Kovacs, 1956). Citrate utilization test was carried out by streak inoculating the bacterium on simmon's citrate agar slant (Schaad, 1988). After incubation green colour of simmon's citrate agar slant changed into a bright blue colour indicated positive test. For motility indole urease agar (MIU) test, pure colony of bacterium was stub inoculated into the 
motility indole urease agar (Schaad, 1988). Bacterium migrated away from the original line of inoculation after $48 \mathrm{hr}$ of incubation indicated positive test. Gelatine liquefaction test was performed by stub inoculating the bacterium into the tube containing $12 \%(\mathrm{w} / \mathrm{v})$ gelatin. After 24 hours of incubation gelatin liquefied microorganisms were determined by the formation of liquid culture after keeping it at $5^{\circ} \mathrm{C}$ in refrigerator for 15 minutes (Salle, 1961). Pectiolytic test was performed by spot inoculating the bacterium in sterile distilled water on a nick of potato slice placed on a petri dish (Goszczynska et al., 2000).

\subsection{Pathogenicity test}

A bacterial suspension $(5 \mu \mathrm{l})$ containing $10^{8}$ colony forming units per $\mathrm{ml}\left(\mathrm{CFU} \mathrm{ml} \mathrm{m}^{-1}\right)$ was inoculated into potato tuber with a sterile syringe. The control tuber was inoculated with same amount of sterile water. Tubers were then placed in polyethylene bags, which were tightly sealed and incubated in the dark at $25^{\circ} \mathrm{C}$ for $7-$ 14 days. After incubation, the tubers were cut in half longitudinally through the inoculation site with a sterile knife and examined for the extent of soft rot. To confirm Koch's postulates, bacteria reisolated from diseased tubers were streaked on NA plate and reidentified using the methods outlined by Lelliott and Stead (1987).

\subsection{Isolation and purification of biocontrol agents}

Trichoderma harzianum from Bangladesh Agricultural Research Institute (BARI), Gazipur and Aspergillus flavus from Plant Pathology Laboratory of Sher-e-Bangla Agricultural Unversity (SAU), Dhaka were isolated and purified on PDA plates following the method described by Ashrafuzzaman (1976). Antagonistic bacteria were isolated from rhizosphere soil of dhaincha and tomato plant by dilution plate technique as described by Goszczynska and Serfontein (1998). One gram of soil was placed in the test tube containing $9 \mathrm{ml}$ of sterile water and stirred thoroughly for few minutes. Tenfold dilution was made from this solution, which was repeated four times to make final dilution up to $10^{-4}$. One hundred micro litre of each dilution was spreaded over NA plate, King's B (KB) plate and YMA plate at three replications and incubated at $30 \pm 1^{\circ} \mathrm{C}$ for $48 \mathrm{hr}$. Colonies of bacteria were purified on NA plates. For isolation of spore forming Bacillus subtilis, stock solution was heated at $85^{\circ} \mathrm{C}$ for 10 minutes (Nemeckova et al., 2011).

\subsection{Identification of antagonistic bacteria}

Identification of antagonistic bacteria was done by gram's staining reaction (Gerhardt, 1981), potassium hydroxide $(3 \% \mathrm{KOH})$ test (Suslow et al., 1982), starch hydrolysis test (Cowan, 1974), catalase test (Schaad, 1988), oxidase test (Kovacs, 1956), citrate utilization test (Schaad, 1988), motility indole urease agar (MIU) test (Schaad, 1988) and gelatine liquefaction test (Salle, 1961) as described above.

\subsection{In-vitro screening of chemicals against Erwinia carotovora subsp. carotovora}

A supply of cotton swabs on wooden applicator sticks was prepared following the method described by Vandipitte et al. (1991). Five selected chemicals viz. Cupravit 50 WP (Copper oxychloride), Sulcox 50 WP (Copper oxychloride), Champion 77 WP (Copper hydroxide), Indofil M-45 (Mancozeb) and Bavistin 50 WP (Carbendazim) were screened against the bacterium by well diffusion method measuring the inhibition zone (Anon, 1996). Four wells of $5 \mathrm{~mm}$ in diameter were made in the same NA plate maintaining equal distance and the broth culture of Erwinia carotovora subsp. carotovora was spreaded uniformly on it with sterile cotton swabs. Chemical suspension at definite concentration with different volume was added into the well each at three replications. In case of control, only sterile water was used instead of chemical. The plates were incubated at $30 \pm 1^{\circ} \mathrm{C}$. Zone of inhibition around the wells were measured and recorded after every 24 hours for 5 days. 


\subsection{In vitro screening of biocontrol agents against Erwinia carotovora subsp. carotovora}

Five biocontrol agents viz. Bacillus subtilis, Pseudomonas fluorescens, Rhizobium leguminosarum, Trichoderma harzianum and Aspergillus flavus were screened against the growth of Erwinia carotovora subsp. carotovora by well diffusion method measuring the inhibition zone (Yenjerappa, 2009). Supernatant of biocontrol agents were dropped into the well of previously swabbed plate with the pathogenic bacteria each at three replications. In case of control, only sterile water was used instead of supernatant. The plates were then incubated at $30 \pm 1^{\circ} \mathrm{C}$. Zone of inhibition around the wells were measured and recorded after every 24 hours for 5 days.

Data on different parameters were analyzed by using computer software MSTAT-C (Anon., 1989) and level of significant differences under different treatments and parameters were determined.

\section{Results and Discussion}

\subsection{Isolation and purification of the causal organism}

The infected potato tuber yielded well separated, round, convex, creamy white colonies of Erwinia carotovora subsp. carotovora on NA plates after 48 hours of incubation at $30 \pm 1^{\circ} \mathrm{C}$ (Fig. 1). Similar types of colonies were found by Abd ElKhair and Karima (2007).

\subsection{Identification of the pathogen}

The isolated bacteria identified as Erwinia carotovora subsp. carotovora according to its morphological and biochemical characters (Table 1).

The bacterium was rod shaped with rounded ends, cells appeared singly and also in pairs, gram negative (red colour) and capsulated under the compound microscope at 100x magnification with oil immersion. It produced a mucoid thread when lifted with the loop, showed amylase activity, formed bubbles after adding $3 \% \mathrm{H}_{2} \mathrm{O}_{2}$, formed dark purple colour on oxidase disk, used citrate as a carbon source for their energy, migrated away from the original line of inoculation, gelatin was liquefied and decayed the potato slice (Fig. 2). These results agreed with those recorded by Pérombelon (2002), Schaad et al. (2001) and Cuppels and Kelman (1974).

\subsection{Pathogenicity test}

The characteristic symptoms were observed on potato tuber after ten days of inoculation as small, water-soaked spots on the surface. These spots were rapidly enlarged and the tissue was decomposed in a soft, blister-like area on the surface of the tuber. Re isolation was carried out from these lesions and comparison was made with the original culture to confirm the identity of the pathogen. Artificially inoculated plants yielded the bacterial colonies similar to the original ones.

Table 1. Reaction of isolated Erwinia carotovora subsp. carotovora to different tests

\begin{tabular}{lc}
\hline Name of tests & Reaction \\
\hline Gram's staining & + \\
KOH solubility test & + \\
Starch hydrolysis test & + \\
Catalase test & + \\
Oxidase test & + \\
Citrate utilization test & + \\
Motility indole urease agar (MIU) test & + \\
Gelatine liquefaction test & + \\
Pectiolytic test & + \\
\hline
\end{tabular}




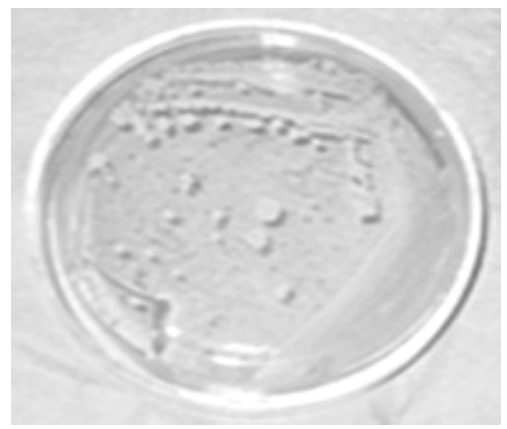

Fig. 1. Pure culture of Erwinia carotovora subsp. carotovora

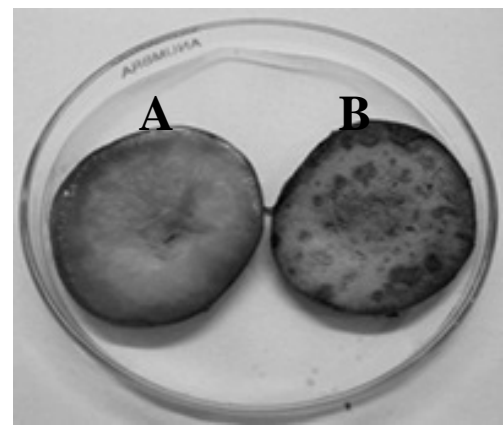

Fig. 2. Pectiolytic test for Erwinia carotovora subsp. carotovora (A. control and inoculated potato slice)
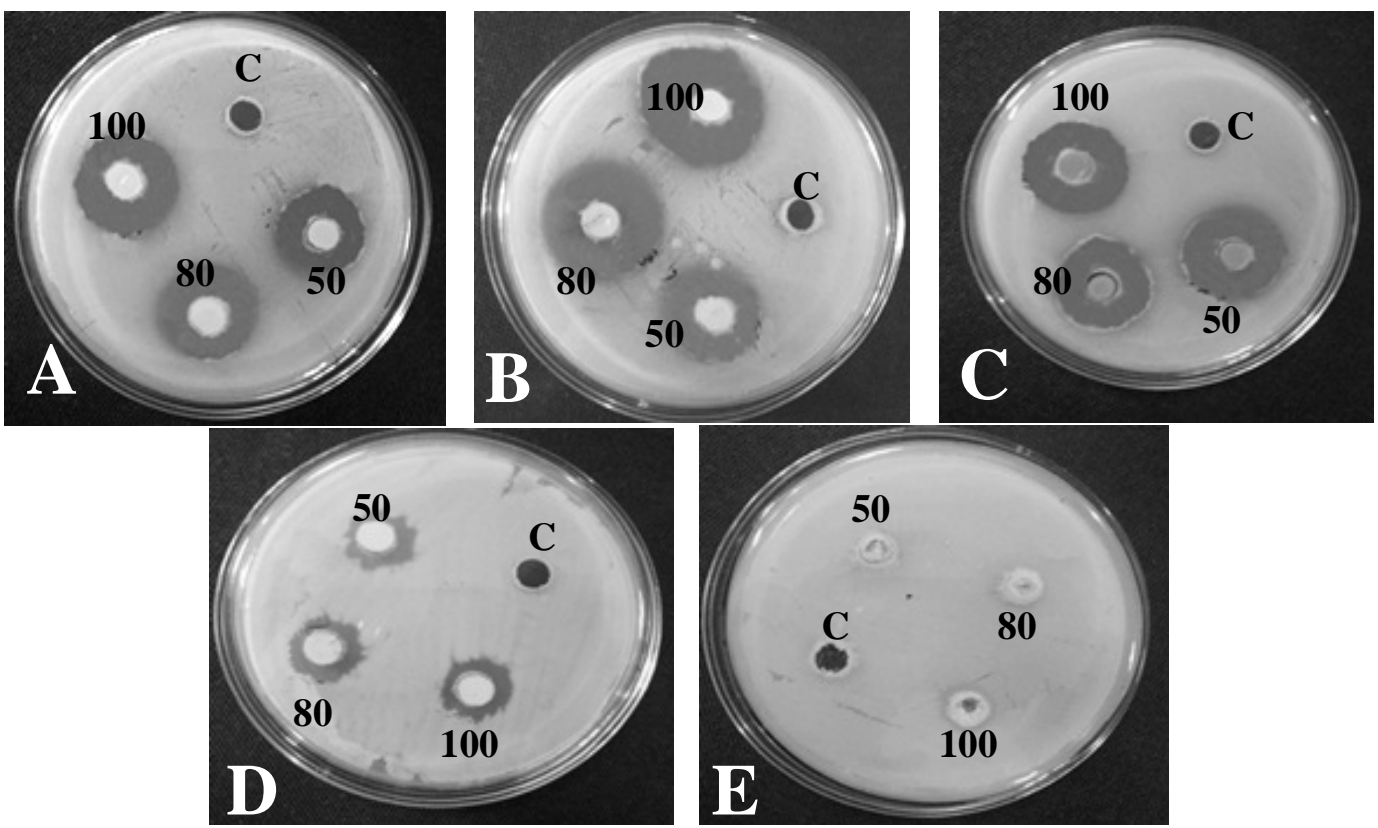

Fig. 3. Screening of different chemicals against Erwinia carotovora subsp. carotovora

(A) Cupravit $50 \mathrm{WP}$ (B) Sulcox $50 \mathrm{WP}$ (C) Champion 77 WP (D) Indofil M-45 and

(E) Bavistin $50 \mathrm{WP}$ after 48 hours of incubation

\subsection{In-vitro screening of chemicals against Erwinia carotovora subsp. carotovora}

Among the five chemicals, Sulcox 50 WP (Copper oxychloride) showed the highest inhibition zone after $24(28.00 \mathrm{~mm}), 48(31.00$ $\mathrm{mm}), 72(29.33 \mathrm{~mm}), 96(26.67 \mathrm{~mm})$ and 120 hours $(23.67 \mathrm{~mm})$ of incubation at $0.2 \%$ concentration when $100 \mu \mathrm{l} /$ well was used where Bavistin 50 WP (Carbendazim) showed the lowest inhibition zone (Table 2 and Fig. 3). Garza et al. (2002) reported that copper-based compounds suppressed soft rot bacterial growth at various cupric ion concentrations in vitro. 
Table 2. Comparative efficacy of some chemicals against Erwinia carotovora subsp. carotovora

\begin{tabular}{|c|c|c|c|c|c|c|c|}
\hline \multirow{2}{*}{$\begin{array}{l}\text { Antibacterial } \\
\text { chemicals }\end{array}$} & \multirow{2}{*}{$\begin{array}{c}\text { Conc. } \\
(\%)\end{array}$} & \multirow{2}{*}{$\begin{array}{l}\text { Volume } \\
(\mu \mathrm{l})\end{array}$} & \multicolumn{5}{|c|}{ Inhibition zone (mm) } \\
\hline & & & $24 \mathrm{~h}$ & $48 \mathrm{~h}$ & $72 \mathrm{~h}$ & $96 \mathrm{~h}$ & $120 \mathrm{~h}$ \\
\hline $\begin{array}{l}\text { Cupravit } \\
50 \mathrm{WP}\end{array}$ & 0.2 & 100 & $26.67 \mathrm{~b}$ & $29.00 \mathrm{~b}$ & $26.33 \mathrm{~b}$ & $24.33 \mathrm{~b}$ & $20.67 \mathrm{~b}$ \\
\hline $\begin{array}{l}\text { Sulcox } \\
50 \mathrm{WP}\end{array}$ & 0.2 & 100 & $28.00 \mathrm{a}$ & $31.00 \mathrm{a}$ & $29.33 \mathrm{a}$ & $26.67 \mathrm{a}$ & $23.67 \mathrm{a}$ \\
\hline $\begin{array}{l}\text { Champion } \\
77 \mathrm{WP}\end{array}$ & 0.2 & 100 & $25.67 \mathrm{~b}$ & $28.33 \mathrm{~b}$ & $26.00 \mathrm{~b}$ & $23.33 \mathrm{c}$ & $21.00 \mathrm{~b}$ \\
\hline $\begin{array}{l}\text { Indofil } \\
\mathrm{M}-45\end{array}$ & 0.3 & 100 & $19.33 \mathrm{c}$ & $18.67 \mathrm{c}$ & $16.33 \mathrm{c}$ & $13.67 \mathrm{~d}$ & $11.67 \mathrm{c}$ \\
\hline $\begin{array}{l}\text { Bavistin } \\
50 \mathrm{WP}\end{array}$ & 0.3 & 100 & $10.33 \mathrm{~d}$ & $0.00 \mathrm{~d}$ & $0.00 \mathrm{~d}$ & $0.00 \mathrm{~d}$ & $0.00 \mathrm{~d}$ \\
\hline $\mathrm{CV} \%$ & & & 2.99 & 4.59 & 2.79 & 2.74 & 3.56 \\
\hline
\end{tabular}

Each data represents the mean of three replications.

Values followed by the same letter within a column are not significantly different $(\mathrm{p} \leq 0.05)$ according to Duncan's multiple range test.
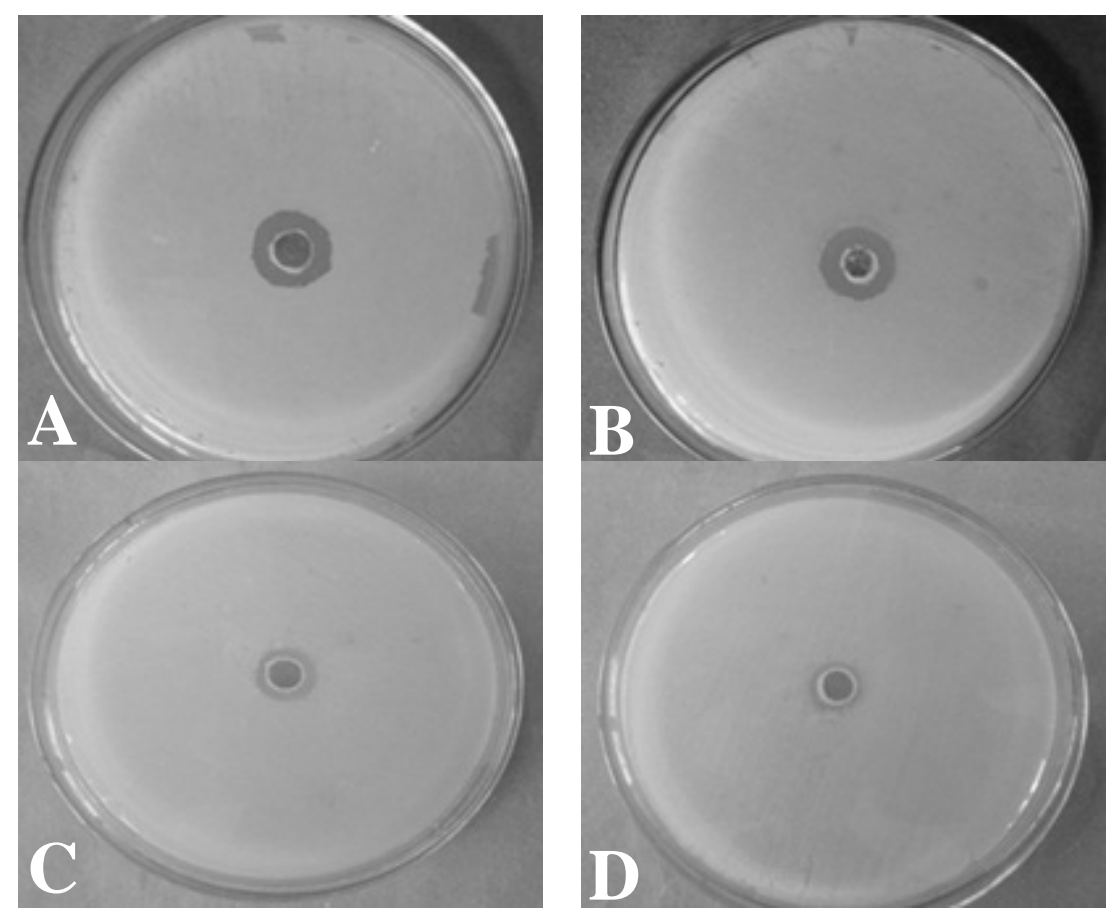

Fig. 4. Screening of different biocontrol agents against Erwinia carotovora subsp. carotovora

(A) Bacillus subtilis (B) Trichoderma harzianum (C) Pseudomonas fluorescens and

(D) Rhizobium leguminosarum after 48 hours of incubation 
Table 3. Efficacy of some biocontrol agents against the growth of Erwinia carotovora subsp. carotovora

\begin{tabular}{lrrrrl}
\hline Biocontrol agent & \multicolumn{5}{c}{ Inhibition zone (mm) } \\
\cline { 2 - 6 } & $24 \mathrm{~h}$ & $48 \mathrm{~h}$ & $72 \mathrm{~h}$ & $96 \mathrm{~h}$ & $120 \mathrm{~h}$ \\
\hline Bacillus subtilis & $14.33 \mathrm{~b}$ & $16.67 \mathrm{a}$ & $15.67 \mathrm{a}$ & $13.33 \mathrm{a}$ & $9.33 \mathrm{a}$ \\
Pseudomonas fluorescens & $11.67 \mathrm{c}$ & $14.33 \mathrm{~b}$ & $13.33 \mathrm{~b}$ & $12.00 \mathrm{~b}$ & $8.00 \mathrm{~b}$ \\
Rhizobium leguminosarum & $11.33 \mathrm{c}$ & $13.67 \mathrm{~b}$ & $13.33 \mathrm{~b}$ & $11.33 \mathrm{~b}$ & $7.67 \mathrm{~b}$ \\
Trichoderma harzianum & $16.33 \mathrm{a}$ & $13.67 \mathrm{~b}$ & $0.00 \mathrm{c}$ & $0.00 \mathrm{c}$ & $0.00 \mathrm{c}$ \\
Aspergillus flavus & $0.00 \mathrm{~d}$ & $0.00 \mathrm{c}$ & $0.00 \mathrm{c}$ & $0.00 \mathrm{c}$ & $0.00 \mathrm{c}$ \\
Control & $0.00 \mathrm{~d}$ & $0.00 \mathrm{c}$ & $0.00 \mathrm{c}$ & $0.00 \mathrm{c}$ & $0.00 \mathrm{c}$ \\
\hline CV\% & 5.65 & 4.47 & 5.59 & 7.11 & 8.76 \\
\hline
\end{tabular}

Each data represents the mean of three replications.

Values followed by the same letter within a column are not significantly different $(\mathrm{p} \leq 0.05)$ according to Duncan's multiple range test.

\subsection{In-vitro screening of biocontrol agents against Erwinia carotovora subsp. carotovora}

Among the five biocontrol agents, Bacillus subtilis, Pseudomonas fluorescens, Rhizobium leguminosarum and Trichoderma harzianum were significantly superior in inhibiting the growth of Erwinia carotovora subsp. carotovora (Table 3 and Fig. 4). Bacillus subtilis showed highest inhibition zone $(16.67 \mathrm{~mm})$ after 48 hours of incubation followed by Trichoderma harzianum with inhibition zone $(16.33 \mathrm{~mm})$ after 24 hours of incubation (Table 3). Aspergillus flavus was ineffective as it failed to inhibit the growth of Erwinia carotovora. Long et al. (2003) reported that the genus Bacillus and Pseudomonas have antagonistic activity against various plant pathogenic bacteria including soft rot bacterium E. carotovora subsp. carotovora in vitro. Similar results were also observed by Abd El-Khair and Karima (2007); Raju et al. (2006). Abd El-Khair and Karima (2007) reported that $T$. harizanum and $B$. subtilis were strangely effective in reducing the soft rot disease.

\section{Conclusions}

Erwinia carotovora subsp. carotovora, the causal agent of soft rot of potato was isolated from the infected tuber and was identified. The present findings revealed that among the five selected chemicals Sulcox 50 WP (Copper oxychloride) was highly effective and among the five biocontrol agents, Bacillus subtilis was highly effective against this pathogen in vitro.

\section{References}

Abd-El-Khair, H. and Karima, H. E. H. 2007. Application of some bactericides and bioagents for controlling the soft rot disease in potato. Research Journal of Agricultural Biological Science, 3(5): 463-473.

Anonymous. 1996. The Indian Pharmacopoeia. $3^{\text {rd }}$ ed. Ministry of Health and family welfare. Government of India, New Delhi, India, $48 \mathrm{p}$.

Anonymous. 1989. Manual on Mango cultivation in Bangladesh. Horticulture Division. BARI and FAO/UNDP mango improvement and development [BGD/81/022], $1 \mathrm{p}$.

Ashrafuzzaman, M. H. 1976. Laboratory Manual of Plant Pathology. $1^{\text {st }}$ ed. Jaman Manjil, Iqbal Nagar, Khulna, Bangladesh, 97 p.

Backman, P. A., Wilson, M. and Murphy, J. F. 1997. Bacteria for biological control of plant diseases. In: Environmentally Safe Approaches to Crop Disease Control. Eds. N. A. Rechcigl and J. E. Rechcigl. Boca Rota: CRC Press, 95-109 pp. 
Blom, T. J. and Brown, W. 1999. Preplant copper-based compounds reduce Erwinia soft rot on calla lilies. Horticulture Technology, 9(1): 56-59.

Compant, S., Duffy, B., Nowak, J., Clement, C. and Barka, E. A. 2005. Use of plant growth-promoting bacteria for biocontrol of plant diseases: principles, mechanisms of action and future prospects. Applied and Environmental Microbiology, 71: 4951-4959.

Cowan, S. T. 1974. Cowan and Steel's Manual for the Identification of Medical Bacteria, $2^{\text {nd }}$ ed. Cambridge University Press, Cambridge, 67-83 pp.

Cuppels, D. and Kelman, A. 1974. Evaluation of selective media for isolation of soft rot bacteria from soil and plant tissue. Phytopathology, 64: 468-475.

Czajkowski, R., Perombelon, M. C. M., van Veen, J. A. and van der Wolf, J. M. 2011. Control of blackleg and tuber soft rot of potato caused by Pectobacterium and Dickeya species: a review. Plant Pathology, 10: 1365-3059.

Garza, J. A. G., Blom, T. J., Brown, W. and Allen, W. 2002. Pre and post-plant applications of copper-based compounds to control Erwinia soft rot of calla lilies. Canadian Journal of Plant Pathology, 24(3): 274-280.

Gerhardt, P. 1981. Manual of methods of General Bacteriology. American Society of Microbiology, Washington DC, USA, $127 \mathrm{p}$.

Goszczynska, T. and Serfontein, J. J. 1998. Milk Tween Agar, a semiselective medium for isolation and differentiation of Pseudomonas syringae pv. syringae, Pseudomonas syringae pv. phaseolicola and Xanthomonas axonopodis pv. phaseoli. Journal of Microbiological Methods, 32(1): 65-72.

Goszczynska, T., Serfontein, J. J. and Serfontein, S. 2000. Media and diagnostic tests. In: Introduction to Practical Phytobacteriology. $1^{\text {st }}$ ed. Ultra Litho
(Pty) Ltd, Johannesburg, South Africa, 61-73 pp.

Huang, H. H. C. 1997. Biological control of soilborne diseases in Canada. In: International Symposium on Clean Agriculture, Sapporo: OECD, 52-59 pp.

Kovacs, N. 1956. Identification of Pseudomonas pyocyanea by the oxidase reaction. Nature, 178: 703.

Lelliott, R. A. and Stead, D. E. 1987. Methods in Plant Pathology. Volume 2. Methods for the diagnosis of bacterial diseases of plants. British Society for Plant Pathology, Blackwell Scientific Publications, Oxford, UK, 91-105 pp.

Long, H. H., Furuya, N., Kurose, D., Takeshita, M. and Takanami, Y. 2003. Isolation of endophytic bacteria from Solanum sp. and their antibacterial activity against plant pathogenic bacteria. Journal of the Faculty of Agriculture, Kyushu University, 48(1-2): 21-28.

Nemeckova, I., Solichova, K., Roubal, P., Uhrova, B. and Svirakova, E. 2011. Methods for detection of Bacillus sp., $B$. cereus, and B. licheniformis in raw milk. Czech Journal of Food Science, 29 (Special Issue): S55-S60.

Pérombelon, M. C. M. 2002. Potato diseases caused by soft rot Erwinia: An overview of pathogenesis. Plant Pathology, 51:1-12.

Raju, M. R. B., Vijai, P. and Jalali, I. 2006. Antagonistic rhizospheric bacteria for management of bacterial soft rot of radish seed crop. Annual Plant Protection Science, 14(2): 393-395.

Salle, A. J. 1961. Fermentation of carbohydrates and related compounds. In: Laboratory manual on Fundamental Principles of Bacteriology. $5^{\text {th }}$ ed. McGraw Hill Book Company, Inc. New York, USA, 94-98 pp.

Schaad N. W., Jones, J. B. and Chun, W. 2001. Laboratory Guide for Identification of Plant Pathogenic Bacteria. $3^{\text {rd }}$ ed. American Phytopathological Society, St. Paul, MN, USA, 378 p. 
Schaad, N. W. 1988. Initial identification of common genera. In: Laboratory Guide for Identification of Plant Pathogenic Bacteria. $2^{\text {nd }}$ ed. APS Press, St. Paul, Minn, USA, 1-58 pp.

Suslow, T. V., Schroth, M. N. and Isaka, M. 1982. Application of a rapid method for gram differentiation of plant pathogenic and saprophytic bacteria without staining. Phytopathology, 72: 917-918.

Sutton, T. B. 1996. Changing options for the control of deciduous fruit tree diseases. Annual Review of Phytopathology, 34: 527-547.
Vandepitte, J., Engbreak, K., Piot, P. and Heuck, C. C. 1991. Basic Laboratory Procedure in Clinical Bacteriology. World Health Organization, Geneva, 97 p.

WFP. 2013. World Food Programme of United Nations. Agricultural Production and National Food Balance. Rome, Italy.

Yenjerappa, S. T. 2009. Epidemiology and management of bacterial blight of pomegranate caused by Xanthomonas axonopodis pv. punicae (Hingorani and Singh). Ph.D. Thesis. Department of Plant Pathology, University of Agricultural Sciences, Dharwad, USA, 21-123 pp. 